\title{
THE USE OF CASE STUDIES IN THE BUSINESS ENGLISH LANGUAGE TEACHING
}

\author{
Angela Strelchonok, Iveta Ludviga, Riga International School of Economics and Business \\ Administration, str@apollo.lv
}

The paper is concerned with methodological aspects of using Case studies in Business English language teaching at University level. It emphasizes the benefits and opportunities of the Case study method as well as the role Case studies play in practicing and developing language, business communication and managerial skills. The paper analyses Case study as an example of Task-Based Learning (TBL) method which focuses on communicative approach towards problem solving tasks presented in authentic Case studies. The paper deals with language and subject matter integration in the creation and implementation of Case studies in the Business English classroom which involves collaborative work of English language and subject matter lecturers. The integrated approach strengthens both students' subject matter knowledge and language competence. The result of lecturer collaboration is the creation of Case study "Rukisu teja" which is based on a real Latvian family-run business and can be incorporated into both Business English and Entrepreneurship courses.

UDC Number: 81-11, DOI: 10.12955/cbup.2013.27

Key words: business, English, case, integration, language, subject matter

\section{Introduction}

The paper discusses our experience in teaching Business English language to first and second-year students at Riga International School of Economics and Business Administration. As our higher school offers only the two-year course of Business English, we clearly understood that old-fashioned methods of teaching Business English focusing on teaching lexical and grammatical structures could not be used. Instead Content-Based Language Instruction (CBI) was implemented in the Business English classroom with the focus on Task-Based Learning (TBL) approach. It was realised that language skills cannot be taught in entire isolation from other areas of the school curriculum. A special need was felt to relate work done in the Business English classes to that done in other classes and to the school curriculum. In other words, form cannot be separated from content. Business English course covers topic areas varying from Human Resource and Management to Marketing and Accounting. The focal point is that Business English is not taught as a subject separated from the students' real world; instead, it is integrated into the school curriculum. Business English combines professional subject matter and English language teaching. Such a combination is highly motivating because students are able to apply what they learn in their English classes to their main field of study. Being able to use the language skills that they learn in a meaningful context reinforces what is taught and increases their motivation. If students believe that in a language course they do tasks relevant for their future professional communication, they are more motivated to learn (Donna, 2000). 


\section{Content Based Language instruction}

The integration of language and content instruction is a growing phenomenon in the language instruction. $\mathrm{CBI}$ is the integration of particular content with language teaching aims the concurrent teaching of academic subject matter and second language skills (Brinton et al., 1989). The goal of CBI is to prepare students to acquire the languages while using the context of any subject matter so that students learn the language by using it within the specific context. CBI approaches view the target language largely as the vehicle through which subject matter content is learned rather than as the immediate object of study (Brinton et al., 1989). Language has primacy and content facilitates language growth. The advantages of Content Based Language Instruction are well known: students are taught considerable amount of language through interesting and stimulating content, they make connections between the language and what they already know within the context of a specific academic subject, students feel motivated as complex information is delivered through real life context. In order to successfully complete an academic task, a Task Based Learning approach has been implemented in CBI classes.

\section{Task Based Learning}

Jane Willis (1996), in her book 'A Framework for Task-Based Learning', outlines a method called Task-Based Learning (TBL), which is associated with the communicative approach and takes account of the need for authentic communication. What is a task? A task is an activity where the target language is used by the learner for a communicative purpose (goal) in order to achieve an outcome (Willis, 1996). The focus in the task is on meaning not on form.

TBL provides learners with natural exposure (input), chances to use language to express what they want to mean (output), to focus on improving their own language and to analyse and practise forms. TBL is more likely to keep learners motivated since it builds on whatever language they know in a positive way. Learners are actively engaged throughout the task cycle, and get chances to think for themselves and express themselves in the security of their group. They are more autonomous and feel empowered, gaining satisfaction from successfully achieving things through language (Willis et al., 2007).

Pedagogically, task based language teaching has strengthened the following principles and practices: a needs-based approach to content selection, an emphasis on learning to communicate through interaction in the target language, the introduction of authentic texts into the learning situation, the provision of opportunities for learners to focus not only on language but also on the learning process itself, an enhancement of the learner's own personal experiences as important contributing elements to classroom learning, the linking of classroom language learning with language use outside the classroom (Nunan, 2004).

The main advantages of TBL are that language is used for a genuine purpose meaning that real communication should take place, and that at the stage where the learners are preparing their report for the whole class, they are forced to consider language form in general rather than concentrating on a single form. The range of tasks available (reading texts, listening texts, problem-solving, role-plays, questionnaires, etc) offers a great deal of flexibility in this model and should lead to more motivating activities for the learners (Bowen, 2002). Jane Willis (1996) identified seven types of speaking and writing tasks which can successfully be used in the Business English classroom, among which are problem solving tasks: case studies, real-life problems, negotiations, etc. 


\section{Case study}

A case study describes a problematic real-life situation that needs to be solved. Business case studies begin with the description of a company profile followed by additional information presented in the form of charts, graphs and tables. Students are faced with real world tasks and given the authority to decide how to solve business problems using the target language they have already acquired at Business English classes and knowledge of subject areas gained in special courses. It is a useful taskbased activity representing the student centered approach. Think about the traditional teacher centered method, in which the instructor is the hub and all communication goes through him or her. Learning a language and communication skills requires active participation. If only one student can speak at a time, how much learning can be accomplished? With the case study method, on the other hand, students are allowed to communicate in their individual groups, thereby multiplying the opportunities to produce language and to be corrected, as well as to practice communication skills (Rodgers, 2006).

It provides an opportunity

- to practice a variety of business topics relating to Human Resources, Management, Marketing, Finance

- to practice and develop language skills: reading, listening, speaking and writing,

- to practice and develop a variety of business communication skills relating to agreeing and disagreeing, checking and clarifying, discussing advantages and disadvantages, justifying proposals and reaching agreement, chairing and participating in meetings, negotiating a contract, giving a presentation, etc.,

- to develop analytical, managerial skills such as team working, decision making, problem solving as well as critical thinking and reflective learning,

- to develop linguistic competence by consolidating already acquired and being introduced to new lexis,

- to develop writing competence by taking the minutes, writing the agenda of the meeting and as a follow-up activity writing a letter, memorandum, a report, an e-mail, etc.,

- to develop students' organizational skills and encourage collaborative learning.

\section{Stages of the case study}

The following are the main stages of the case study:

- case study introduction,

- defining the problem,

- problem solving,

- presenting the solution(s),

- evaluating the solution(s),

- follow-up (optional),

- feedback. 
When the students are engaged in fluency activity, it is better for the teacher to circulate unobtrusively, making language notes. At the end of the discussion the teacher feeds back the language by writing selected language points in context one by one on the board giving students a chance to supply words or correct mistakes first. When students give presentations the teacher may write individual feedback sheets for students, making it easier for them to review their mistakes out of class (Emmerson, 2007). Instead of leading the class, the teacher's role becomes that of a discussion facilitator who monitors discussions and provides the students with vocabulary, grammatical structures and content feedback.

\section{The use of case studies to develop business communication skills}

The teacher should pre-teach the language required to discuss the case study. It is important to select the skill you would like to focus on and teach the specific language. If we take meetings as an example, we could provide students with useful language input for both the chairperson and the participants, such as the language of agreeing and disagreeing, hedging, expressing opinions, checking understanding, interrupting, referring back, reaching agreement, finding a compromise, coming to a consensus, making your point, making recommendations, inviting people to speak, opening and closing the meeting, etc. If we take negotiations as an example, we could pre-teach the language of putting forward a proposal, agreeing and disagreeing with a proposal, imposing conditions, making concessions, asking for clarification, summarising what has been said, postponing a decision or playing for time, concluding a deal, etc. After finding a solution to the problem the students make presentations in groups. Students should be familiarised with presentation skills, such as introducing the talk, indicating the structure and sequences of your talk, moving from one section of your talk to another, highlighting, summarising, inviting questions, etc. Business English materials, which have structured and lexical approach to business skills (Emmerson, 1999a; Emmerson, 1999b; Emmerson, 1999c; Mascull, 2002; Goodale, 1997) have been successfully used in the Business English classroom for practicing and developing students' communication skills. If students hold a press conference, the teacher should pre-teach the skills of asking and answering difficult questions, using various intonations ranging from neutral and/or polite to forceful and/or aggressive (Cotton et al., 2011a).

\section{Creation of language case studies}

There is a big difference between case studies used in other disciplines and language case studies. The former may be 10-40 pages long and the content is the key element of the case study, the correctness and details of which are emphasized. The latter are short; content is less detailed and is of minor importance. Content of language case studies is a tool and the language becomes the objective of the activity. Results are assessed mainly for their linguistic competence. Such famous authors of „Market Leader" series of pre-intermediate, intermediate, upper intermediate and advanced course books as David Cotton, David Falvey and Simon Kent (Cotton et al., 2010a,b; 2011a,b) as well as Mark Powell with Ron Martinez and Rosi Jillet (Powell et al., 2004) and Tonya Trappe with Graham Tullis (Trappe et al., 2005; 2006) integrated mini cases and/or dilemmas at the end of each chapter dealing with specific business topic, whereas John Allison with Mark Powell (Allison et al., 2005) collected 28 realistic Business English case studies in a separate book which is part of the "In Company" series. "Business Roles 1 and 2" (Crowther-Alwyn, 1997; 2007) are very valuable resource books containing numerous simulations with prescribed roles for students of Business English. David Evans (Evans, 2003) offers 14 business situations for analysis and discussion, Marjorie Rosenberg (Rosenberg, 2005) created activities with the element of fun, Paul Emmerson (2007) suggests interesting topics for 
discussion and provides numerous activities for teaching business communication skills, Adrian Wallwork (1997a,b) wrote very valuable books for intermediate and advanced students containing many topic-based discussions. All these teacher resource books have been successfully used in the Business English classroom.

Language specialists of our school have developed a practice of designing our own language case studies in collaboration with subject matter specialists, thus integrating subject matter content and language development for students since language instructors cannot cope alone with the complexity of the various disciplines. The integration between these two domains results in enhanced learning in both domains as each domain complements and reinforces the other. The disciplines interact and support each other. This approach strengthens both subject matter knowledge and language development. A subject matter specialist acts not only as an adviser to the content, purveyor of information but can also contribute to the design of the case study. The role of the language teacher is to ensure language accuracy and provide detailed teaching notes which help students develop a whole range of language and communication skills. The result of this successful collaboration is the creation of the case study "Ruķisu teja" which is based on a real Latvian family-run company.

\section{Case synopsis}

\section{Background}

"Ruķisu teja" is one of the biggest herbal tea manufacturing companies in Latvia employing 7 permanent and 20 seasonal workers. The company was established in 2000 as a family business having two owners Raimonds Lignickis and his wife Iveta Lignicka. Currently, more than 5 thousand kilos of herbs growing on more than 20 hectares of land are gathered annually and over 50 species of different herbs are used as ingredients for teas packaged as mono-teas as well as tea mixtures. The idea of the business is based on Latvian tradition of drinking herbal teas which have always been considered valuable for their healing properties. The company strongly believes in the value of plants grown in Latvia because customers consider that they should consume only local plants as the latter contain substances necessary for their health. Consumers like products that have roots in the past and a connection with Latvian history, products that create a feeling of belonging and tradition, products that evoke nostalgia. The brand is built on strong associations with cultural Latvian elements laying emphasis on traditional Latvian values. The company cares about its reputation for quality and reliability. Chamomile, peppermint and other plants are harvested manually in order to maintain the high quality and preserve valuable properties of a product. The process of drying takes place in a dryhouse which fully meets the EU standards and requirements of Latvian Food and Veterinary Service.The motto of the company has remained the same for many years: "We produce ecologically clean products from plants grown in Latvia without the use of chemicals or fertilizers."

\section{Problems faced by the company}

As of 2000 the company experienced an average 50\% annual turnover growth but in 2011 it reached the maximum production capacity. And there were truly objective reasons for that: economic crisis, insufficient land resources for growing larger crops of herbs, seasonal character of the business and last but not least unpredictable weather in Latvia. The problem of obtaining a larger amount of herbs could be solved by buying cheaper plants from southern countries where due to hot weather several crops are usually harvested during the year and adding them to tea mixtures. But Raimonds finds this unacceptable as he always puts quality first and is proud of his herbal teas being made of ecological 
plants grown only within the climate zone where Latvian people live without using any fertilizers or chemicals.

\section{Dilemma}

The main aim is to ensure sustainable growth of the company. How can this be achieved? Should the company increase production capacity by adding cheaper overseas herbs into tea mixtures and thus expand the range of products but lose its brand identity, reputation for quality and emphasis on traditional Latvian values or should it stay at the current production capacity but maintain its brand identity and reputation for manufacturing eco herbal teas grown in Latvia without using any fertilizers or chemicals?

\section{Strategy 1}

To ensure sustainable growth the company should buy several hectares of agricultural land to increase crop yields and maintain its reputation for manufacturing eco herbal teas. It should buy new machinery; implement innovative production and crop harvesting techniques; fill the line by adding new products to an existing range, stretch the product line to the high end by developing new exclusive herbal products which will be sold at the highest price; diversify into new products; cut costs by outsourcing some operations; open own tea houses where people could have first-hand experience of company teas.

\section{Strategy 2}

To ensure sustainable growth the company should buy cheap overseas herbs and make tea mixtures out of them and by stretching the product line to the low end sell them at the lowest price; conduct market research to find out whether the product needs a new name and logo, what market segment it should target, whether the design and appearance of the package should be changed, whether the company should continue to sell the product in pharmacies and supermarkets or use a wider variety of outlets; what tools the company should use to promote its product.

Task 1. All students work as one group. You are independent consultants invited by the director of "Ruķisu teja" to analyze the company strengths and weaknesses, identify opportunities and threats within the company's external environment, evaluate the company mission, goals and decide if it can continue at its current pace successfully.

Task 2. Work in groups of 4-6 students. Hold a meeting to discuss advantages and disadvantages of either strategy. Choose one strategy, evaluate all the given options, consider any other options of your own and prepare an action plan. Then meet as one group and present your solutions to other students.

Task 3. As one group decide which strategy 1 or 2 will be a) the most risky b) the most expensive. Arrive at the consensus on the best strategy for the company.

Task 4. As an independent consultant write a report to the director of "Ruķisu teja" containing your findings and recommendations.

\section{Conclusion}

In this paper a closer look has been taken at the teaching methods that are implemented in the Business English classroom, the activities that our students are engaged in and the materials and tasks that are 
created by our specialists. Sound teaching practices have been incorporated to promote language and content learning and to use Content-Based Language Instruction as a framework for language and content learning. The appropriate steps have been taken to implement Task-Based Learning which helps to engage students in increasingly challenging problem solving tasks- case studies which provide a high motivation for students as they are put into real-life situations and find themselves in the position of authority to decide how to solve business problems. The creation of case studies results in successful collaboration of English language and subject matter lecturers where the former focus on the linguistic aspects and the latter are responsible for the academic content. The integration of subject matter with language development reinforces both science knowledge and language competence.

\section{References}

Allison, J. \& Powell, M. (2005). In Company Case studies. Oxford, England: Macmillan.

Bowen, T. (2002). Task-Based Learning. One stop English website. Retrieved from http://www.onestopenglish.com

Brinton, D. M., Snow, M. A., \& Wesche, M. B. (1989). Content-based second language instruction. New York, NY: Newbury House.

Comfort, J., Revell, R. \& Stott, C. (1998). Business Reports in English. (fifteenth edition). Cambridge, England: Cambridge University Press. PMCid:PMC20214

Cotton, D., Falvey, D. \& Kent, S. (2010a). New Edition Market Leader. Pre-Intermediate Business English Course Book. (sixth edition). Harlow, England: Pearson Longman.

Cotton, D., Falvey, D. \& Kent, S. (2010b). Intermediate Market Leader. Business English Course Book. (third edition). Harlow, England: Pearson Longman.

Cotton, D., Falvey, D. \& Kent, S. (2011a). Upper-Intermediate Market Leader. Business English Course Book. (third edition). Harlow, England: Pearson Longman.

Cotton, D., Falvey, D. \& Kent, S. (2011b). Advanced Market Leader. Business English Course Book. (third edition). Harlow, England: Pearson Longman.

Crowther-Alwyn, J. (1997). Business Roles 1. Cambridge, England: Cambridge University Press.

Crowther-Alwyn, J. (2007). Business Roles 2. (third edition). Cambridge, England: Cambridge University Press.

Donna, S. (2000). Teach Business English. Cambridge, England: Cambridge University Press.

Emmerson, P. (2007). Business English Frameworks. (third edition). Cambridge, England: Cambridge University Press. PMCid:PMC2675363

Emmerson, P. (1999a). Business Builder. Modules 1, 2, 3. Intermediate Teacher's Resource Series. Oxford, England: Macmillan.

Emmerson, P. (1999b). Business Builder. Modules 4, 5, 6. Intermediate Teacher's Resource Series. Oxford, England: Macmillan. 
Emmerson, P. (1999c). Business Builder. Modules 7, 8, 9. Intermediate Teacher's Resource Series. Oxford, England: Macmillan.

Evans, D. (2003). Decisionmaker. (fourth edition). Cambridge, England: Cambridge University Press.

Goodale, M. (1997). The Language of Meetings. (eighth edition). Hove, England: Language Teaching Publications.

Nunan, D. (2004). Task-Based Language Teaching. Cambridge, England: Cambridge University Press. http://dx.doi.org/10.1017/CBO9780511667336

Mascull, B. (2002). Business Vocabulary in Use. Cambridge, England: Cambridge University Press.

Powell, M., Martinez, R. \& Jillet, R. (2004). New Business Matters. London, England: Thomson Heinle.

Rodgers, D. (2006). Business Communications. International Case Studies in English. (sixth edition). Cambridge, England: Cambridge University Press.

Rosenberg, M. (2005). In Business. Cambridge, England: Cambridge University Press.

Taylor, S. (1999). Communication for Business. (third edition). Harlow, England: Pearson Longman.

Trappe, T. \& Tullis, G. (2005). Intelligent Business. Coursebook. Intermediate Business English. Harlow, England: Pearson Longman.

Trappe, T. \& Tullis, G. (2006). Intelligent Business. Coursebook. Upper Intermediate Business English. Harlow, England: Pearson Longman.

Wallwork, A. (1997a). Discussions A - Z Advanced. Cambridge, England: Cambridge University Press.

Wallwork, A. (1997b). Discussions A-Z Intermediate. Cambridge, England: Cambridge University Press.

Willis, J. (1996). A Framework for Task-Based Learning. Harlow, England: Pearson Longman.

Willis, D. \& Willis, J. (2007). Doing Task-Based Teaching. Oxford, England: Oxford University Press. 